\title{
UJI AKTIVITAS ANALGETIK EKSTRAK ETANOL 96\% DAUN BELIMBING WULUH (Averrhoa bilimbi L.) DENGAN METODE GELIAT PADA MENCIT PUTIH (Mus musculus L) GALUR SWISS WEBSTER
}

\author{
Ni Putu Ovy Darmayanti ${ }^{1}$, Ni Putu Rahayu Artini ${ }^{2}$, Putu Yudhistira Budhi Setiawan ${ }^{3}$ \\ Program Studi Farmasi Klinis, Fakultas Ilmu-Ilmu Kesehatan \\ Universitas Bali Internasional \\ Email :darmayantiovy@gmail.com
}

\begin{abstract}
Abstrak
Analgetik adalah zat atau suatu bahan yang dapat menekan ataupun menghilangkan rasa nyeri dengan tidak menghilangkan kesadaran. Daun belimbing wuluh mengandung flavonoid yang memiliki potensi sebagai analgetik. Tujuan dari penelitian ini untuk mengetahui apakah ekstrak daun dari tanaman Averrhoa bilimbi L. memiliki aktivitas analgetik terhadap mencit putih jantan. Penelitian ini menggunakan rancangan penelitian eksperimental murni dengan tipe penelitian adalah post test only control group design Pengujian aktivitas analgetik ditunjukan dengan adanya respon geliat kemudian dapat dilakukan uji analisis statistika One Way ANOVA dan Post Hoc LSD. Hasil penelitian menunjukan bahwa ekstrak etanol $96 \%$ daun belimbing wuluh memiliki aktivitas analgetik pada mencit putih jantan. Berdasarkan uji One Way Anova, antara kelompok perlakuan dengan kontrol positif memiliki perbedaan bermakna dengan nilai signifikansi sebesar $0.000(\mathrm{p}<0.05)$. Hasil analisis data uji post hoc LSD menunjukkan bahwa terdapat perbedaan bermakna antara kelompok perlakuan dosis $125 \mathrm{mg} / \mathrm{kg} \mathrm{BB}, 250$ $\mathrm{mg} / \mathrm{kg}$ BB dengan kontol positif. Simpulan dari penelitian ini adalah dosis $500 \mathrm{mg} / \mathrm{kg}$ BB ekstrak etanol 96\% daun belimbing wuluh (Averrho bilimbi L) pada mencit memiliki efek analgesik dengan persentase penghambat geliat yaitu $68.49 \%$ dan mendekati kontrol positif parasetamol dengan dosis $65 \mathrm{mg} / \mathrm{kg} \mathrm{BB}$ sebesar $80.36 \%$.
\end{abstract}

Kata kunci:Analgetik, Daun belimbing wuluh, Geliat.

\begin{abstract}
Analgesics are substances or substances that can suppress or eliminate pain by not eliminating awareness. Averrhoa bilimbi leaf contain flavonoids which have analgesic potential. The Purpose of this study aims to determine whether leaf extracts from the Averrhoa bilimbi. plant have analgesic activity against male white mice. This study uses a purely experimental research design with the type of research is the post test only control group design. Analytical activity testing is indicated by the existence of stretching responses and then the One Way ANOVA and Post Hoc LSD statistical analysis tests can be performed. The results showed that $96 \%$ ethanol extract of Averrhoa bilimbi leaf had analgesic activity in male white mice. Based on the One Way Anova test, between the treatment groups with positive controls had a significant difference with a significance value of $0.000(p<0.05)$. The results of post hoc LSD test data analysis showed that there was a significant difference between the treatment group dose $125 \mathrm{mg} /$ $\mathrm{kg}$ body weight, $250 \mathrm{mg} / \mathrm{kg}$ body weight with positive dick. The conclusion of this study is the dose of $500 \mathrm{mg} / \mathrm{kg}$ of ethanol extract $96 \%$ of Averrhoa bilimbi leaf (Averrho bilimbi L) on mice has analgesic effect with the stretching percentage of $68.49 \%$ and approaches the positive control of paracetamol with a dose of $65 \mathrm{mg} / \mathrm{kg} \mathrm{BW}$ of $80.36 \%$.
\end{abstract}

Keywords:Analgesic, Averrhoa bilimbi, and writhing test 


\section{Pendahuluan}

Masyarakat Indonesia sekarang ini semakin banyak yang menuju paradigma "Back to Nature" yaitu lebih memilih menggunakan bahan alam dalam mengatasi masalah kesehatan. Pemanfaatan tanaman sebagai media obat sebagai salah satu media penyembuhan penyakit. Kekayaan alam khusus nya di Bali membuat masyarakat Bali mengenal pengobatan tradisional.

Salah satu tanaman yang dapat ditemukan dengan mudah dipekarangan rumah dan memiliki banyak manfaat bagi pengobatan kesehatan yaitu, tanaman belimbing wuluh (Averrhoa bilimbi L.). yang merupakan family dari Oxalidaceae. Pada kehidupan sehari - hari bagian dari tanaman belimbing wuluh sangat bermanfaat khususnya pada bagian daunnya. Secara empiris daun dari tanaman belimbing wuluh digunakan sebagai obat diabetes, obat batuk, obat hipertensi, obat darah tinggi, obat nyeri, obat rematik, obat sakit kepala, demam, sakit perut di masyarakat(Aulia, 2018).

Daun belimbing wuluh mengandung berbagai senyawa metabolit sekunder yaitutanni, flavonoid, saponin, steroid, alkaloid, serta triterpen(Kusumaningtyas et.al., 2008). Flavonoid merupakan suatu senyawa metabolit sekunder yang bertanggung jawab memberikan pengaruh analgetik dengan cara menghambat biosintesis prostaglandin sehingga akibatnya dapat mengurangi rasa nyeri (Puspitasari et.al., 2002; Nurdiana, 2000).

Berdasarkan hal tersebut, maka dilakukan penelitian dengan daun belimbing wuluh yang diekstraksi dengan menggunakan pelarut etanol $96 \%$. Metode yang dilakukan dalam penelitian ini adalah metode geliat atau writhing test yaitu dengan melihat adanya efek proteksi terhadap rasa sakit akibat pemeberian asam asetat secara intraperitonial pada mencit percobaan. Ekstrak diberikan sebagai efek proteksi untuk menunjukan keefektifan bahan uji yang diduga berfungsisebagai analgetik.

\section{MetodePenelitian Objek Penelitian}

Objek yang diteliti adalah ektrak etanol 96\% daun belimbing wuluh (Averrhoa bilimbi L.) dengan 3 dosis orientasi berbeda- beda untuk mengetahui aktifitas analgetik pada mencit putih jantan (mus musculus) menggunakan metode induksi nyeri secara kimia.

\footnotetext{
Alat

Alat-alat yang digunakan adalahstopwatch, timbangan analitik (analytical balance), spuit untuk
}

injeksi, sonde oral, pipet tetes, baskom, toples, pisau, corong, kertas saring, batang pengaduk, kandang untuk mencit serta wadah minum

\section{Bahan}

Bahan - bahan yang digunakan yaitu daun belimbing wuluh, larutan etanol 96\%, Na-CMC, asam asetat glasial, aquadest, parasetamol Serbuk $\mathrm{Mg}$ dan HCL.

\section{Uji Fitokimia}

Uji flavonoid

Identifikasi flavonoid dilakukan dengan cara menambahkan serbuk Mg dan HCL $2 \mathrm{~N}$ pada sampel ektrak etanol $96 \%$ daun belimbing wuluh, menunjukan warna merah.

\section{Objek Makhluk Hidup Yang Digunakan}

Objek makhluk hidup yang digunakan merupakan mencit putih (mus musculus L.) jantan berumur 2-3 bulan dengan berat badan 20 -30gram.

\section{Uji Efek Analgetik}

Metode yang digunakan pada penelitian ini adalah metode geliat. Mencit diadaptasi terlebih dahulu selama 6 hari didalam lingkungan penelitian. Mencit dikelompokkan secara acak menjadi 5 kelompok, dimana masing - masing kelompok terdiri atas 5 mencit.Sebelum penelitian dimulai mencit dipuasakan selama kurang lebih 12 jam dengan tetap memberikan minum.

Pada kelompok kontrol negatif, setiap mencit diberikan akuades secara oral Pada kelompok kontrol positif, setiap mencit di berikan parasetamol dengan dosis $65 \mathrm{mg} / \mathrm{kg}$ BBsecara oral. Pada kelompok perlakuan satu, setiap mencit diberikan dosis ekstrak uji dengan dosis $125 \mathrm{mg} / \mathrm{kg}$ BB secara oral. Pada kelompok perlakuan dua diberikan dosis ekstrak uji dengan dosis $250 \mathrm{mg} / \mathrm{kg}$ BB secara oral. Pada kelompok perlakuan dua diberikan dosis ekstrak uji dengan dosis $500 \mathrm{mg} / \mathrm{kg}$ BB. secara oral. 30 menit setelah pemberian perlakuan, diinduksi menggunakan indikator nyeri secara intraperitonial (i.p) menggunakan asam asetat. Geliat diamati setiap 5 menit selama 1 jam dan dihitung persentase penghambat geliat dengan cara : Perhitungan daya penghambat geliat

$$
\% \text { penghambatan geliat }=100-[(\mathrm{P} / \mathrm{K}) \mathrm{x} 100 \%]
$$

Keterangan :

$\mathrm{P}=$ jumlah geliat komulatif hewan uji setelah perlakuan

$\mathrm{K}=$ jumlah geliat rata -rata hewan uji pada kelompok kontrol negatif 


\section{Analisis Data}

Data kumulatif jumlah geliat mencit tiap 5 menit selama 1 jam dari lima kelompok perlakuan diuji kenormalan dan data homogenitas variasi. Apabila varian terdistribusi normal dan homogen dilanjutkan dengan mencari signifikasi hubungan antara kelima kelompok perlakuan menggunakan ANOVA satu arah. Apabila terdapat perbedaan bermakna antara 5 kelompok perlakuan dilanjutkan dengan mencari signifikasi antar kelompok uji menggunakan uji post hoc dengan uji LSD (Least Significantly Different)

\section{Hasildan Pembahasan}

\subsection{Hasil Determinasi Tanaman}

Hasil identifikasi menunjukan bahwa tanaman uji yang dipergunakan adalah tanaman jenis belimbing wuluh (Averrho bilimbi L) yang termasuk ke dalam suku Oxalidaceae.

\subsection{Identifikasi Flavonoid}

Identifikasi senyawa flavonoid yang dilakukan untuk mengetahui adanya senyawa flavonoid dalam ekstrak etanol $96 \%$ daun belimbing wuluh dengan menggunakan pereaksi serbuk magnesium $(\mathrm{Mg})$ dan asam klorida pekat $(\mathrm{HCl})$. ikatan dengan gugus karbonil pada senyawa flavonoid dapat terbentuk dengan adanya penambahan serbuk Mg. Pembentukan garam flavilium yang ditandai dengan perubahan warna menjadi merah, jingga, hijau, dan kuning terjadi apabila adanya penambahan $\mathrm{HCl}$.

Flavonoid berperan sebagai analgesik yang mekanisme kerjanya menghambat kerja enzim siklooksigenase. Dimana enzim siklooksigenase berperan dalam menstimulasi pelepasan mediator nyeri, yaitu prostaglandin.

\subsection{Pengujian Aktivitas Analgetik}

Penelitian ini dilakukan untuk mengetahui aktivitas analgetik dari ekstrak etanol daun Sereh Wangi terhadap mencit putih jantan dengan menggunakan dosis orientasi yang dilakukan kepada mencit putih jantan. Tujuan dibuatnya dosis orientasi agar mengetahui dosis optimal yang dapatberguna sebagai efek analgetik pada mencit putih jantan.

Pada uji Aktivitas analgetik ini menggunakan metode induksi nyeri cara kimia atausering juga disebut metode Writhing test rangsang kimia yang digunakan yaitu Penggunaan Asam asetat, dipilih karena dapat memberikan rangsang nyeri yang cukup baik terhadap hewan uji dengan memicu pelepasan asam arakidonat bebas dari jaringan fosfolipid melalui siklooksigenase(Gunawan et.al 2008).

Geliat yang dihitung adalah geliat dengan ciriciri terjadinya kontraksi otot perut dengan gerakan peregangan dari anggota badan ke belakang yaitu tarikan kaki ke belakang, serta terjadinya perluasan seluruh tubuh. Rata - rata jumlah geliat setiap 5 menit selama 1 jam dapat dilihat pada tabel 1 .

Tabel 1. Rata - rata Jumlah Geliat selama 1 jam

\begin{tabular}{|c|c|r|}
\hline kelompok uji & $\begin{array}{c}\text { Perla- } \\
\text { kuan }\end{array}$ & $\overline{\mathrm{X}} \pm \mathrm{SD}$ \\
\hline I & PN & $146,0 \pm 11,533$ \\
\hline II & PP & $28,67 \pm 6,028$ \\
\hline III & P1 & $91,00 \pm 10,440$ \\
\hline IV & P2 & $72,00 \pm 7,000$ \\
\hline V & P3 & $46,00 \pm 14,177$ \\
\hline
\end{tabular}

Keterangan :

$\mathrm{PN}=$ Kontrol negatif ( aquadest)

$\mathrm{PP}=$ Kontrol positif (parasetamol)

$\mathrm{P} 1=$ Kelompok perlakuan dosis $125 \mathrm{mg} / \mathrm{kg} \mathrm{BB}$

$\mathrm{P} 2=$ kelompok perlakuan dosis $250 \mathrm{mg} / \mathrm{kg} \mathrm{BB}$

$\mathrm{P} 3=$ Kelompok perlakuan dosis $500 \mathrm{mg} / \mathrm{kg} \mathrm{BB}$

Hasil dari pengujian efek analgetik pada tanaman belimbing wuluh didapatkan jumlah geliat rata-rata mencit yang menujukkan bahwa terdapat penurunan jumlah rata-rata geliat pada mencit yang termasuk kedalam kelompok kontrol positif maupun pada kelompok ekstrak bila dibandingkan dengan kelompok kontrol negatif. Hal ini menunjukkan bahwa pada kelompok pemberian ekstrak dan parasetamol (kontrol positif) dapat mengurangi terjadinya geliat pada mencit. Semakin sedikit jumlah rata-rata geliat yang ditunjukan oleh kelompok mencit maka akan semakin baik efek analgesik pada suatu bahan uji.

Setelah mengetahui jumlah geliat, maka dihitung persentase penghambat geliat bahan uji yang digunakan, maka akan diketahui seberapa efektif bahan uji bekerja sebagai obat analgetik dibandingkan dengan kontrol positif (parasetamol) yang digunakan. Data persentase penghambar geliat dapet dilihat pada Tabel 2.

Tabel 2. Persentase (\%) penghambat geliat 


\begin{tabular}{|c|c|c|}
\hline kelompok uji & $\begin{array}{l}\text { Perla- } \\
\text { kuan }\end{array}$ & $\begin{array}{c}\text { Penghambat } \\
\text { geliat } \\
(\%)\end{array}$ \\
\hline I & PN & 0,00 \\
\hline II & PP & 80,36 \\
\hline III & P1 & 37,67 \\
\hline IV & P2 & 50,68 \\
\hline V & P3 & 68,49 \\
\hline
\end{tabular}

Kelompok dosis yang menunjukkan persentase proteksi terbesar atau mendekati persentase proteksi pada kelompok perlakuan kontrol positif terdapat pada kelompok dosis P3 sebesar $68,49 \%$, yang artinya dosis P3 merupakan dosis yang efektif memberikan efek analgesik. Belimbing wuluh dapat memberikan efek analgetik.

Untuk lebih membuktikan bahwa ektrak etanol 96\% daun belimbing wuluh mempunyai kemampuan sebagai obat analgetik, maka dilakukan analsis data secara statistik. Hasil uji normalitas dan homogenitas varian menunjukan bahwa data sudah terdistribusi normal dan homogen dimana nilai $(\mathrm{P}>0,05)$. dan analisis statistik dengan ANOVA menghasilkan nilai signifikasi yang lebih kecil dari 0,05 yaitu 0,000 yang menunjukkan prosentase rata-rata geliat berbeda signifikan. Sehingga perlu dilakukannya uji LSD untuk menunjukan pada kelompok mana yang mengalami perbedaan yang signifikan. Hasil uji LSD menunjukan bahwa pada kelompok perlakuan kontrol positif dan kelompok perlakuan pada dosis tiga menunjukkan efek analgesik yang tidak berbeda bermakna $(p>0,05)$ terhadap kelompok positif atau pada obat parasetamol, sehingga dapat dikatakan bahwa pada kelompok perlakuan dosis tiga dan kelompok kontrol positif tersebut memiliki efek analgesik.

Aktivitas analgesik yang ditimbulkan diduga karena adanya kandungan senyawa flavonoid dari daun belimbing wuluh. Flavonoid berperan sebagai analgesik yang mekanisme kerjanya menghambat kerja enzim siklooksigenase. Dimana enzim siklooksigenase berperan dalam menstimulasi pelepasan mediator nyeri , yaitu prostaglandin(Gunawan et.al 2008).

\section{Simpulan dan Saran}

\section{Simpulan}

Dari hasil dan pembahasan penelitian diperoleh simpulan, dosis $500 \mathrm{mg} / \mathrm{kg}$ BB ekstrak etanol $96 \%$ daun belimbing wuluh (Averrho bilimbi L) pada mencit memiliki efek analgesik dengan persentase penghambat geliat yaitu $68.49 \%$ dan mendekati kontrol positif parasetamol dengan dosis $65 \mathrm{mg} / \mathrm{kg}$ BB sebesar $80.36 \%$ ditinjau dari penurunan jumlah geliat mencit jantan yang diinduksi menggunakan asam asetat.

\section{Saran}

Saran yang dapat disampaikan pada penelitian ini adalah perlu dilakukan penelitian lebih lanjut dengan proses fraksinasi menggunakan pelarut lain untuk mengetahui senyawa aktif yang berpotensi sebagai analgetik. Dan perlu dilakukan pengujian toksisitas akut maupun kronis untuk menunjang tingkat keamanan penggunaan daun belimbing wuluh (Averrho bilimbi L) sebagai sediaan herbal.

\section{Daftar Pustaka}

Aulia R. Setyaningsih. Endang. 2018. Potensi Tanaman Belimbing Wuluh (Averrhoa bilimbi) Terhadap Beberapa Penyakit Pada Sistem Cardiovascular. Mahasiswa Pendidikan Biologi, FKIP Universitas Muhammadiyah Surakarta. Lyche, T., and Morken, K., 2004. SplineMethods, Draft,

Retrievedfromhttp://www.ub.uio.n./umn/english/i ndex.html, on 23th Feb 2005.

Faharani, G. B. 2009, Uji Aktifitas Antibakteri Daun belimbing Wuluh Terhadap Bakteri Streptococcus Aureus Dan Echeria Coli secara Bioautografi. Jakarta: Universitas Indonesia.

Fransius, P.S., Mangaratua. 2008. Penampilan Reproduksi Mencit (Mus musculus) yang Diberi Daun Torbangun Kering. Program Studi Teknologi Produksi Ternak Fakultas Peternakan. Bogor: Institut Pertanian Bogor

Gunawan, S.G., Setiabudy, R., Nafrialdi, Elsyabeth, 2008, Farmakologi dan Terapi Edisi 5, Fakultas Kedokteran Universitas Indonesia. Jakarta

Mario Parikesit. 2011. Khasiat dan manfaat buah belimbing wuluh. Surabaya : Stomata. h.1$8 ; 67-68$.

Marlyne Riza, 2012, Uji Efek Analgesik dan Antiinflamasi Ekstrak Etanol 70\% Bunga Mawar (Rosa chinensisjaca) Pada Mencit yang Diinduksi Asam Asetat, Universitas Indonesia, Jakarta. Indonesia

Mary J. Mycek, Richard A. Harvey, Pamela C. Champe, \& Bruce D. Fisher., 2001, Farmakologi, 2 nd edition, Widya Medika, Jakarta. Indonesia

Puspitasari, H., Listyawati, S., Widiyani, 2002, Aktivitas Analgesik Ekstrak Umbi Teki 
(Cyperus rotundus L) Pada Mencit Putih

(Mus musculus L) Jantan, Biofarmasi, 1(2) 